\title{
DOES THE TICHI HAF DAM CONSTRUCTION AFFECT DRAGONFLY AND DAMSELFLY (ODONATA : INSECTA) ASSEMBLAGES OF THE BOUSSELLAM WATERCOURSE (CENTRAL NORTH ALGERIA)? A PRELIMINARY STUDY
}

\author{
Abdelmadjid Chelli*, Riadh Moulaï and Abdelhadi Djemai
}

Laboratoire de Zoologie Appliquée et d'Ecophysiologie Animale, Faculté des Sciences de la Nature et de la Vie, Université de Bejaia, 06000 Bejaia, Algeria

*Corresponding author. Email: mchelli70@yahoo.fr

Article history Received: 10 February 2020 accepted 15 April 2020

\section{Keywords:}

Bejaia; Odonata;

Boussellam watercourse;

Tichi Haf dam;

anthropization

\begin{abstract}
This paper reports a pioneer study dealing with the impact of dam construction on Odonata communities, because no similar study has been undertaken in Algeria and the consequences of this artificialization on the Odonata assemblages have rarely been studied elsewhere. The main purpose of this study was to determine if the Tichi Haf dam is really having a negative effect on the Odonata communities living on the Boussellam watercourse, as there has hitherto been a lack of knowledge about its odonatofauna and aquatic microinvertebrates. This study showed that changes due to the construction of this dam, involving riparian vegetation, bank aspect and water parameters, affected the Odonata assemblages inhabiting both sides of the dam wall. The richness and abundance of dragonflies and damselflies found upstream from the dam is quite different from those found downstream from the dam. The survey also identified four new species for the Bejaia region. Among these, we report on the rediscovery of the critically endangered (EN) Calopteryx exul in Algeria, recorded in the nineteenth century and deemed to have been extinct after an absence of more than a century. The presence of an extant population C. exul in this location does not correspond to any historical locality reported for this species.
\end{abstract}

\section{INTRODUCTION}

Aquatic ecosystems support rich and diverse assemblages with developed adaptations that allow them to prosper in these environments and which, at the same time, make them very vulnerable to possible alterations in their habitat. In this sense, human activity often causes severe ecological damage to river systems. These disturbances produce alterations in the chemical composition of water and in the structure of the communities of organisms living in this environment (Oller and Goitia 2005). Indeed, these continental aquatic ecosystems, including watercourses, are subject to multiple pressures that alter and make them more fragile (Dudgeon et al. 2006; Remsburg et al. 2008; Riservato et al. 2009; Clausnitzer et al. 2009; Garcia et al. 2010). Among the main threats identified to continental aquatic ecosystems are dams. Most of them are built on rivers with the best of intentions to provide water supplies and power at times when water is naturally scarce and to reduce the devastating effects of floods (Lévêque 2005; Mc Cartney 2009). The report of the World Commission on Dams shows that the benefits derived from these dams are generally positive, but severe in terms of environmental consequences (C.M.B. 2000). In fact, in most cases, these constructions disturb the fauna and flora of the rivers on which they have been built because they alter ecological continuity, modify the hydrological and thermal regime of the river, as well as the artificial riprapping on the banks, and interrupt the continuity of the riparian vegetation (Richter et al. 1997; Dudgeon et al. 2006; Belmar et al. 2010). Changes in marginal vegetation and in flow velocity may produce changes in the composition of aquatic assemblages, with the replacement of some species by others due to the destruction of microhabitats and the creation of new ones (Lessard and Hayes 2003; Fulan et al. 2010; Denis 2018).

According to McCartney (2009), hydraulic infrastructures have fragmented up to $60 \%$ of the world's rivers, and the Mediterranean and North African rivers are not a derogation from the rule. Almost all major rivers in the Mediterranean basin have dam impoundments (Smith and Darwall 2006).

The impact of hydraulic structures on aquatic fauna has been the subject of numerous studies, particularly those devoted to fish fauna and aquatic microinvertebrates (Dessaix et al. 1995; Thorne and Williams 1997; Thomson et al. 2005; Tonkin et al. 2009; Bredenhand and Samways 2009; McCartney 2009).

Few studies specifically dealing with the impact of dam construction on populations of Odonata have been pub- 
lished (Fulan et al. 2010; Clausnitzer et al. 2012; Brasil et al. 2014; Klein et al. 2018; Denis 2018).

This taxon contains species sensitive to environmental changes, making them extremely vulnerable (Riservato et al. 2009). This sensitivity makes Odonata effective as indicator species for reflecting some of the impacts and pressures on aquatic ecosystems. They therefore represent an interesting group for assessing the health of aquatic habitats and their biodiversity (Ferreras-Romero et al. 2009). Although they do not allow determination of biotic indices, through this taxon we can easily get a first glimpse of any anthropization on the quality and structure of aquatic habitats. One of the primary causes of artificialization in rivers is fragmentation by dam construction (Brasil et al. 2014; Klein et al. 2018). However, the consequences of artificialization on Odonata have rarely been studied, and until now most of the studies in Algeria have focused on understanding the habitat and pollution responses of Odonata. This is the reason why this preliminary study was initiated. This report aims to improve knowledge of the potential impact which artificialization can generate on the Odonata of a fluvial system. To accomplish this task, we tested the hypothesis that the richness and density of Odonata would decrease within and downstream from the dam compared with the upstream zone above the dam.

\section{STUDY AREA AND METHODS}

This study was conducted on the Boussellam River near the Tichi Haf dam in Bejaia province, $50 \mathrm{~km}$ southeast of Bejaia town, central north Algeria (Figure 1). Our study area is characterized by a Mediterranean climate, with mild and humid winters alternating with hot and dry summers. There is a rainy season from October to May, and a dry season from June to September. It is subject to high water conditions due to heavy, often irregular, rainfall varying annually between $600 \mathrm{~mm}$ and $800 \mathrm{~mm}$. We sampled three localities (zones, Z1, Z2, Z3) from April to July 2019. The distances sampled were $6 \mathrm{~km}$ between the zone downstream of the Tichi Haf dam (Z3) and the Tichi Haf dam (Z2), $4 \mathrm{~km}$ between $\mathrm{Z} 2$ and the zone upstream of the Tichi Haf dam (Z1), and $10 \mathrm{~km}$ between $\mathrm{Z} 1$ and $\mathrm{Z} 3$.

\section{List of sampling localities (zones)}

The coordinates, altitude in meters above sea level, $\mathrm{pH}$ value, water flow $(\mathrm{m} / \mathrm{s})$, dissolved oxygen $(\%)$, temperatures $\left({ }^{\circ} \mathrm{C}\right)$, riverbed, vegetation and bank characteristics for each of the sampling locations were:

(1) Upstream of Tichi Haf dam: $36^{\circ} 25^{\prime} 60^{\prime \prime} \mathrm{N}, 4^{\circ} 43^{\prime} 141^{\prime \prime} \mathrm{E}$, $325 \mathrm{~m}$ a.s.1., $\mathrm{pH} 8.73$, water flow $0.71 \mathrm{~m} / \mathrm{s}$, dissolved oxygen $21.5 \%$, water temperature $19.2{ }^{\circ} \mathrm{C}$. The width of this zone varies between 35 and 40 metres, its hydrological regime is of a rainfall type with a relatively high current velocity, the bed substrate is often finer, composed of sand, silt or clay, gravel and woody detritus along the shoreline. Its banks are fairly vegetated, mainly composed of Typha angustifolia, Scirpus lacustris, Cyperus longus, Paspalum distichum, Nasturtium officinale, and Apium nodiflorum. They are covered in some places by shrubs and trees, such as Populus nigra, Salix sp., Tamarix gallica, and Nerium oleander, but in some parts they are totally exposed.

(2) Tichi Haf dam: 36 25' $8^{\prime \prime} \mathrm{N}, 4^{\circ} 41^{\prime} 58^{\prime \prime} \mathrm{E}, 300 \mathrm{~m}$ a.s.l., $\mathrm{pH} 8.75$, dissolved oxygen $16.5 \%$, water temperature $22.8^{\circ} \mathrm{C}$. The appearance of this zone is partly similar to lakes. The water is more or less stagnant and muddy on the banks. Shoreline vegetation is dominated by Juncus maritimus, Phragmites australis, Scirpus lacustris, and Tamarix gallica.

(3) Downstream of Tichi Haf dam: $36^{\circ} 25^{\prime} 15^{\prime \prime} \mathrm{N}$, $4^{\circ} 37^{\prime} 9^{\prime \prime} \mathrm{E}, 240 \mathrm{~m}$ a.s.1., $\mathrm{pH} 8.63$, water flow $0.37 \mathrm{~m} / \mathrm{s}$, dissolved oxygen $34.6 \%$, water temperature $19.6{ }^{\circ} \mathrm{C}$.

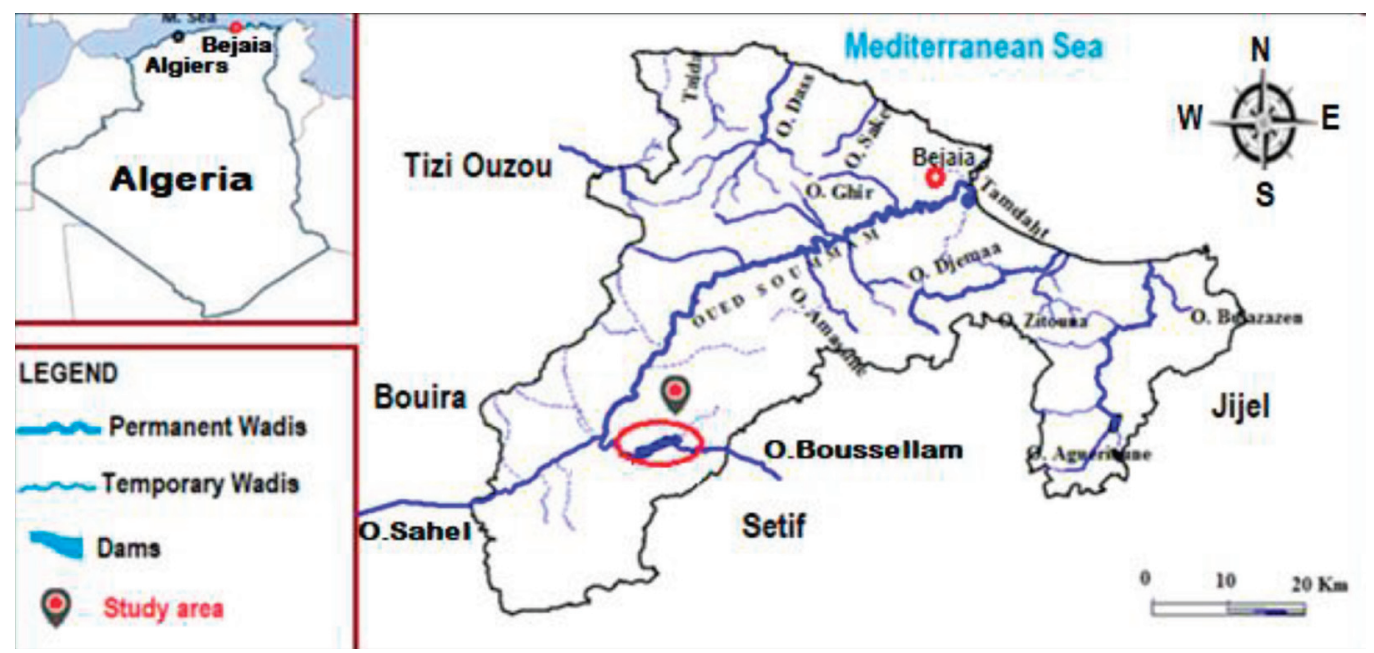

Figure 1. Geographic location of study area in Bejaia region. 
The width of this zone varies between 25 and 30 metres. This area located downstream from the dam has a fairly variable water regime under the effect of this dam, with the exception of the overflow periods and the various emptying operations that take place periodically, the flow is much lower and slower than in the zone upstream. The bed substrate is mainly composed of rocks, gravel and sand. Its banks are less vegetated, composed in some places by Typha angustifolia, Scirpus lacustris, and an arborescent stratum such as Tamarix gallica, Nerium oleander and Calycotome spinosa.

\section{Odonata sampling}

To understand how species richness and composition on a site scale are influenced by ecological processes, it is essential to sample the different life history stages of Odonata (Khelifa 2019). Indeed, it is necessary to resort to sampling larvae, exuviae and imagos. The search for larvae and exuviae allows the observer to obtain valuable information on autochthonous species and to collect additional data on more discreet species or those difficult to capture (Heidemann and Seidenbusch 2002; Raebel et al. 2010). As for this study, which remains preliminary, the surveys focused solely on the recognition of adults for practical reasons, but in the coming years we plan to extend this approach and focus on different life stages for this taxon.

Within each zone, a transect of 1000 metres of bank line was sampled. The transects were divided into ten 100metre sections (Figure 2). On each transect, an exhaustive survey of all Odonata present was carried out over a period of five months (from April to August 2019). Each stretch was surveyed from one of the banks by walking slowly and regularly to identify individuals in the vegetation and over the water. During each visit, the three zones were sampled on the same day. The duration of each visit was about $2 \mathrm{~h}$ under favourable weather, between $10 \mathrm{am}$ and $3 \mathrm{pm}$, during temperatures above $18{ }^{\circ} \mathrm{C}$ to ensure that sampling was performed during the insects' period of highest activity because the vast majority of Odonata are ectothermic, relying on sunlight or ambient heat to warm their bodies (May 1976; Corbet 1999). An additional period of $20 \mathrm{~min}$ was allocated to the immediate surroundings of each zone (herbaceous and woody vegetation, etc.) to record sheltered adults. All the Odonata were identified visually with the aid of a pair of binoculars or caught with a butterfly net when necessary and identified using an aplanatic magnifying glass and relevant identification guides (D'Aguilar and Dommanget 1998; Grand and Boudot 2006). When it was necessary to transport a captured specimen to the laboratory for further identification, the specimen was put in a labelled plastic box.

\section{Data analysis}

The recorded odonatofauna was analyzed using species richness $(\mathrm{R})$, the Shannon index $\left(\mathrm{H}^{\prime}\right)$, and Pielou's evenness index $(\mathrm{J})$. The degree of species composition or species diversity ( $\left.\mathrm{H}^{\prime}\right)$ for each zone was determined by the Shannon index. This index indicates the abundance and evenness of species composition per unit area. The higher the value of H', the greater the diversity and supposedly the cleaner the environment. Homogeneity or the pattern of distribution of species in relation to other species in a sample per zone was calculated using Pielou's evenness index. At the end, we discuss the alarm-
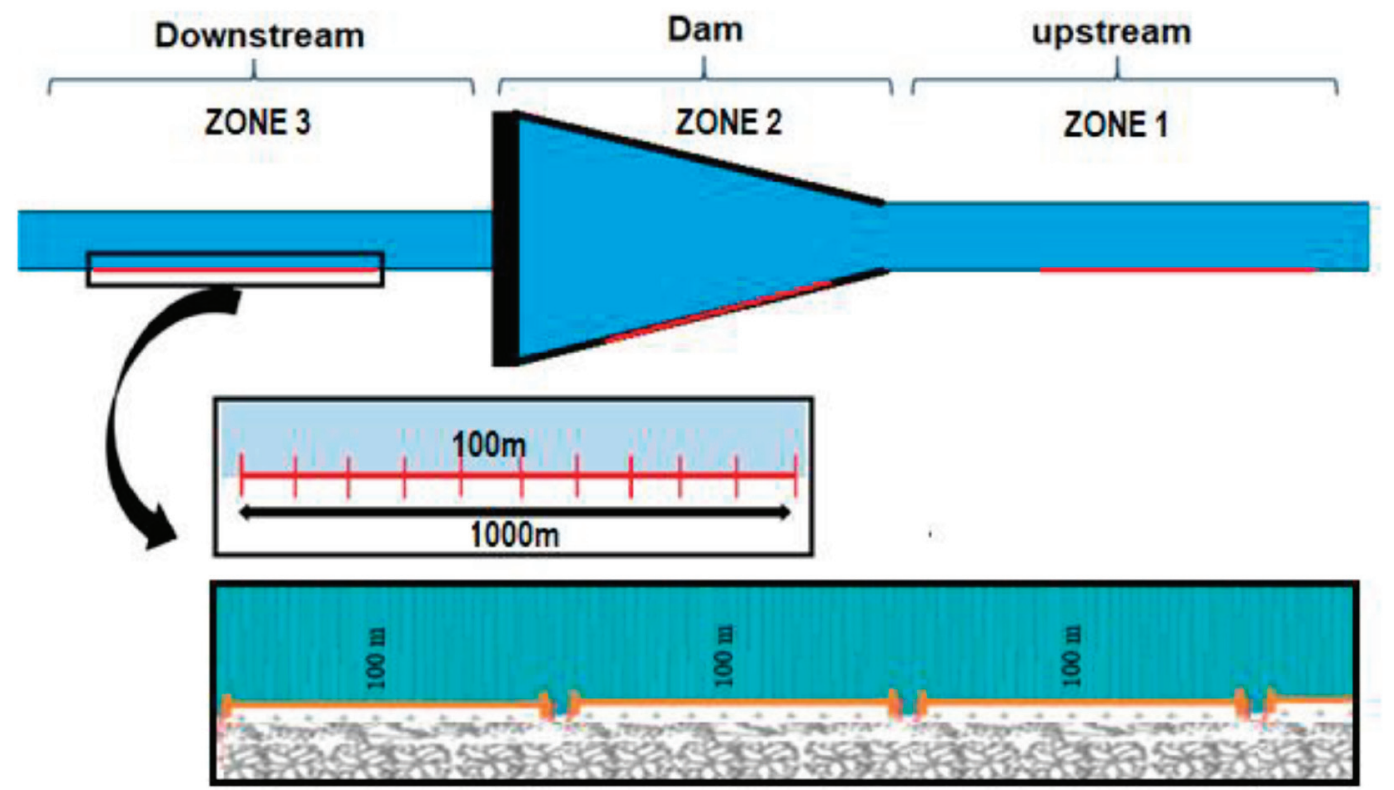

Figure 2. Schematic representation of the Odonata survey protocol in three study zones (Indermuehle et al. 2008; Denis 2018); modified. 
ing situation of two emblematic Odonata, Caloptyrex exul and Onychogomphus uncatus, in the whole country. These two species were selected for their scarcity and low density on local and regional scales. Their rareness is based on a combination of scarcity of occupation, low population abundance, and habitat specificity: (1) a species has a national occupancy rarity when it is only recorded in a maximum of two provinces in the country; (2) a species presents a demographic rarity when there are no sightings or captures of more than ten individuals in all literature citations mentioning the species; and, finally, (3) a species has habitat specificity when it occurs in a maximum of only two typical habitats.

\section{RESULTS}

\section{Odonata species inventoried}

The checklist and abundance of Odonata species recorded in the three zones of the study area during the various monthly visits are given in Table 1 below. The taxa of the "family" group are presented in systematic order, and those of the "genus" and "species" groups are presented in alphabetical order. The status of recorded species is taken from the Mediterranean and North African IUCN Red Lists (Riservato et al. 2009; Samraoui et al. 2010).
Despite a short survey period, a considerable number of Odonata species were identified in the study area. Over five months of surveying, we identified twenty-three (23) Odonata belonging to both suborders, Zygoptera (39\%) and Anisoptera (61\%). They included seven families and seventeen genera. The Libellulidae family was the most diversified with eight taxa, accounting for almost $35 \%$ of all Odonata recorded. The three study zones shared four species, Erythromma lindennii, Ischnura graellsii, Anax imperator, and Hemianax ephippiger. Among the 23 species listed, 19 are assessed on both IUCN Red Lists in category LC (Table 1).

\section{Structure of the Odonata communities}

In order to better determine if the Tichy Haf dam really influences the structure of the Odonata communities on the Boussellam watercourse, abundance, richness and diversity above, within, and below the dam were compared. The results are presented in Table 2 and Figures 3, 4.

The species richness of Odonata collected varied along the three sampling zones ranging from ten species from the Tichi Haf dam (Z2) to a maximum of seventeen species upstream from the dam (Z1). Zygopteran species richness was higher in the upstream zone than in the dam and in the downstream zone, which in turn contained a higher species richness than the dam. However, with

Table 1. The checklist and abundance of Odonata species recorded in three zones: Z1: upstream of the dam; Z2: the dam; Z3: downstream of the dam; *: Common Species; LC: Least Concern; EN: Endangered; NT: Near Threatened; VU: Vulnerable.

\begin{tabular}{|c|c|c|c|c|c|c|}
\hline Sub Order & Family & Species & Status & $\mathrm{Z} 1$ & $\mathrm{Z} 2$ & $\mathrm{Z3}$ \\
\hline \multirow{9}{*}{ 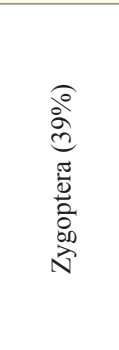 } & \multirow{2}{*}{ Calopterygidae } & Calopteryx haemorrhoidalis (Vander Linden, 1825) & $\mathrm{LC}$ & 305 & 0 & 157 \\
\hline & & Calopteryx exul Selys, 1853 & EN & 81 & 0 & 20 \\
\hline & \multirow{2}{*}{ Lestidae } & Lestes virens (Charpentier, 1825) & LC & 8 & 0 & 0 \\
\hline & & Sympecma fusca (Vander Linden, 1820) & LC & 17 & 0 & 0 \\
\hline & Platycnemididae & Platycnemis subdilatata Selys, 1849 & $\mathrm{LC}$ & 204 & 0 & 42 \\
\hline & \multirow{4}{*}{ Coenagrionidae } & Erythromma lindennii (Selys, 1840)* & $\mathrm{LC}$ & 180 & 87 & 178 \\
\hline & & Ceriagrion tenellum (Villers, 1789) & $\mathrm{LC}$ & 21 & 0 & 150 \\
\hline & & Coenagrion scitulum (Rambur, 1842) & NT & 10 & 28 & 0 \\
\hline & & Ischnura graellsii (Rambur, 1842)* & $\mathrm{LC}$ & 155 & 72 & 78 \\
\hline \multirow{14}{*}{ 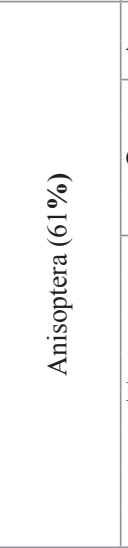 } & \multirow{2}{*}{ Aeshnidae } & Anax imperator Leach, $1815^{*}$ & LC & 19 & 7 & 10 \\
\hline & & Hemianax ephippiger (Burmeister, 1839)* & $\mathrm{LC}$ & 16 & 72 & 3 \\
\hline & \multirow{4}{*}{ Gomphidae } & Gomphus lucasii Selys, 1849 & EN & 0 & 0 & 13 \\
\hline & & Onychogomphus costae Selys, 1885 & NT & 25 & 0 & 0 \\
\hline & & Onychogomphus forcipatus unguiculatus (Vander Linden, 1820) & $\mathrm{LC}$ & 0 & 0 & 28 \\
\hline & & Onychogomphus uncatus (Charpentier, 1840) & $\mathrm{LC}$ & 0 & 0 & 7 \\
\hline & \multirow{8}{*}{ Libellulidae (35\%) } & Brachythemis impartita (Karsch, 1890) & $\mathrm{LC}$ & 0 & 47 & 0 \\
\hline & & Crocothemis erythraea (Brullé, 1832) & $\mathrm{LC}$ & 15 & 26 & 0 \\
\hline & & Orthetrum cancellatum (Linnaeus, 1758) & $\mathrm{LC}$ & 7 & 18 & 0 \\
\hline & & Orthetrum chrysostigma (Burmeister, 1839) & LC & 23 & 0 & 104 \\
\hline & & Orthetrum nitidinerve (Selys, 1841) & LC & 7 & 0 & 0 \\
\hline & & Sympetrum fonscolombii (Selys, 1840) & $\mathrm{LC}$ & 16 & 21 & 0 \\
\hline & & Sympetrum striolatum (Charpentier, 1840) & $\mathrm{LC}$ & 0 & 0 & 50 \\
\hline & & Trithemis annulata (Palisot de Beauvois, 1807) & $\mathrm{LC}$ & 0 & 53 & 71 \\
\hline \multicolumn{3}{|c|}{ Total individuals (all species) (23) } & & $1109(17)$ & $431(10)$ & $911(14)$ \\
\hline \multicolumn{3}{|c|}{ Total individuals (Zygoptera species) (09) } & & $1026(09)$ & $187(03)$ & $625(06)$ \\
\hline \multicolumn{3}{|c|}{ Total individuals (Anisoptera species) (14) } & & $83(08)$ & $244(07)$ & $286(08)$ \\
\hline
\end{tabular}


regard to Anisopteran richness, there was no significant difference between the three study zones (Figure 3).

Abundance was higher for Zygopterans in the upstream zone than in the dam and downstream zones, whereas the abundance of Anisopterans was lower in the upstream zone compared to the other two zones, the dam and the

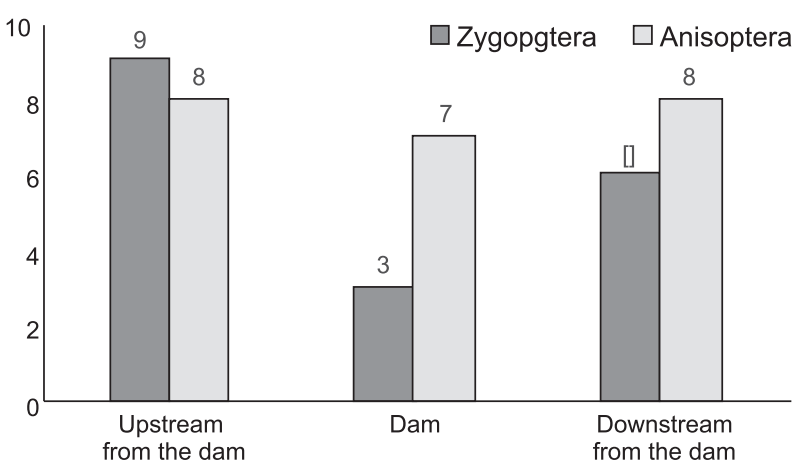

Figure 3. Anisoptera and Zygoptera richness in three study zones.

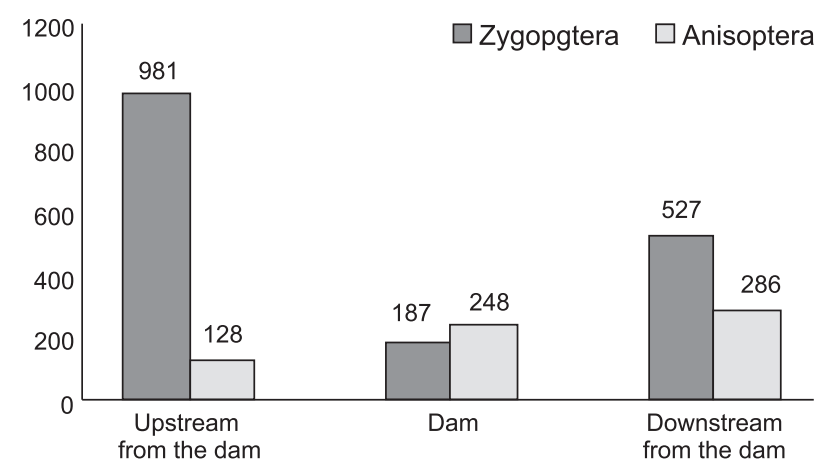

Figure 4. Anisoptera and Zygoptera abundances in three study zones. downstream zone. Both the dam and the downstream zone did not show any difference in the abundance of Anisopterans (Figure 4).

The graph in Figure 5 shows that the upstream zone was relatively richer in species with higher densities of Zygoptera than the downstream zone. This is probably due to the physiognomy of this habitat whose banks are well vegetated and very shady, thus offering favourable conditions for the proliferation of some damselflies such as Calopteryx haemorrhoidalis, Calopteryx exul, Platycnemis subdilatata, Erythromma lindennii, and Ischnura graellsii. Conversely, populations of these species abruptly decreased to a few individuals downstream from the dam. On the other hand, this section of the watercourse seems hospitable to the Anisoptera, which probably requires clear and sunny sites.

Table 2. Species diversity indices for the study zones. $\mathrm{S}$ : species richness; N: species abundance; J': Pielou's evenness index; $\mathrm{H}^{\prime}$ : Shannon index.

\begin{tabular}{|l|c|c|c|c|c|}
\hline Study zones & S & N & H'$^{\prime}$ & H'max & J' \\
\hline Upstream of the dam (Z1) & 17 & 1109 & 3.10 & 4.08 & 0.76 \\
\hline Dam (Z2) & 10 & 431 & 2.85 & 3.16 & 0.90 \\
\hline Downstream of the dam (Z3) & 14 & 911 & 3.18 & 3.80 & 0.83 \\
\hline
\end{tabular}

Analysis of the ecological indices provides an expansive overview of the structure and distribution of Odonata across the three study zones. The Odonata associated with the lentic zone (dam) were less diverse $\left(\mathrm{H}^{\prime}=2.85\right)$ than those associated with the lotic zone (watercourse) where the diversity values were the highest (Table 2).

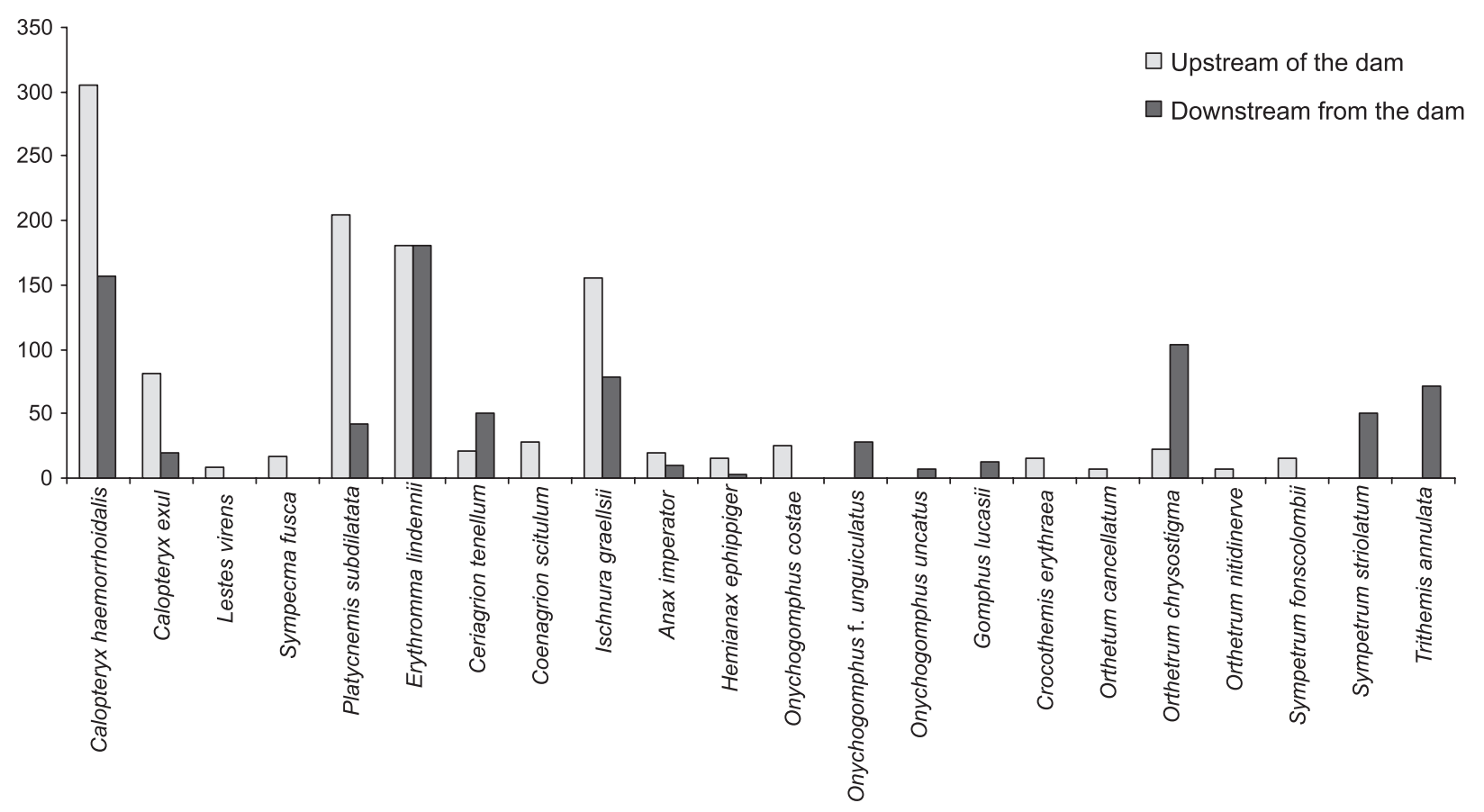

Figure 5. Abundance of Odonata species between the zones upstream and downstream from the dam. 
The richest habitat undoubtedly remained upstream from the dam (Z1) with 17 taxa, where also the greatest abundance of individuals was noted (1109). This high abundance value in this zone is due to a strong proliferation of Coenagrionidae, Calopterygidae and Platycnemididae, as about $75 \%$ of the population is concentrated in four species, namely Calopteryx haemorrhoidalis, Platycnemis subdilatata, Erythromma lindennii, and Ischnura graellsii (Table 1). Indeed, a low value of the Pielou's evenness index (0.76) clearly explains the predominance of some species over others. On the other hand, the highest equitability values were noted in the dam and downstream from the dam with 0.90 and 0.83 , respectively (Table 2).

\section{DISCUSSION}

\section{Odonata sampling}

A total of 2451 individuals of Odonata from seven families, 17 genera, and 23 species were recorded and identified in the present survey. With this richness, the section of the Boussellam River we investigated contains about $37 \%$ of the species discovered so far in Algeria (Samraoui and Menaï 1999) and more than 51\% of the known species of the Numidia (Samraoui and Corbet 2000a, b). None were new to the country, but four Maghrebian and Ibero-Maghrebian endemic taxa are considered new records to the Bejaia area, namely Gomphus lucasii, Onychogomphus costae, Orthetrum nitidinerve, and the discovery of a new population of Calopteryx exul, a critically endangered species in Algeria. The population reported here does not correspond to any historical locality reported for C. exul. These new findings increase the Odonata reference list established by Chelli and Moulai (2019a, b) to 37 species. The Bejaia checklist may be further increased in future, because our odonatological survey in this area is far from complete and further explorations, especially in the most isolated streams, may uncover additional species being likely candidates.

Our results show (Table 1) that Libellulidae, Aeshnidae, and Coenagrionidae are present in lotic and lentic habitats (Z1 and Z3), whereas Gomphidae, Calopterygidae, and Platycnemididae are exclusively lotic (Z2). This finding is verified by Khelifa (2019) in the Seybouse watershed (northeast Algeria). This author also states that lentic species are more likely to disperse and thus to occupy a larger niche breadth than lotic species.

Out of the seven families (3 Anisoptera and 4 Zygoptera) of Odonata recorded, the most represented family was Libellulidae (35\%). This can be explained, on the one hand, by this family comprising the largest number of species in the Maghreb and in the whole Mediterranean basin (Boudot et al. 2009; Riservato et al. 2009; García et al. 2010; Samraoui et al. 2010); on the other hand, the Libellulidae has a clear advantage over Zygoptera and Aeshnidae which are endophyte laying species. Indeed, Libellulidae females release their eggs in contact with or over water, a behaviour that liberates them from a strict dependence on a plant support (Grand 2009). The dominance of the Anisopterans by the Libellulidae family is also mentioned by Dijkstra (2007).

Among the 23 species listed, more than $80 \%$ are assessed on the Mediterranean and North African IUCN Red Lists in the category Least Concern (LC); however, two species, Calopteryx exul and Gomphus lucasii (EN), are considered threatened and one more species, Onychogomphus costae, figures as NT on both Red Lists. On the other hand, Coenagrion scitulum is considered NT on the North African Red List, while being assessed as LC on the Mediterranean Red List (Table1).

\section{Structure of Odonata communities}

In this study, we identified considerable environmental changes due to the construction of the dam on this watercourse. Riparian vegetation was thicker and more diverse upstream and relatively weaker in the affected zones ( $\mathrm{Z} 2$ and $\mathrm{Z3}$ ). As a result of changes in the structure and continuity of riparian vegetation between upstream and downstream zones, we expect that the richness and abundance of some Odonata groups may also change. Indeed, the composition of the Odonata assemblages found upstream from the dam is significantly different from those found within the dam and downstream from the barrier. The higher species diversity $(\mathrm{S}=17)$ as well as a high Shannon diversity index (3.10) recorded upstream from the dam can be attributed to a high spatial heterogeneity and vegetation cover of this habitat. It is important to note that the section of this watercourse (Z1) is characterized by thicker and more diverse vegetation cover along its banks, which serve as perching sites and shelter from predators for less mobile species. Such habitats are known and are expected to have the greatest diversity of Odonata (Kalkman et al. 2008).

The results also showed that the richness of the Odonata was affected by the dam, with different effects on both Anisoptera and Zygoptera sub-orders. As a general pattern, Anisoptera presents higher richness in an altered site; on the other hand, Zygoptera presents higher richness in a preserved one (Carvalho et al. 2013). This pattern suggests, according to these authors, that Odonata needs to be considered at the sub-order level to access the effects of habitat degradation on these insects. When the Odonata are evaluated separately, we found that $\mathrm{Zy}$ goptera richness is higher in the upstream zone (Z1) than in the dammed zones (Z2 and Z3). Therefore, Anisoptera richness does not show a significant difference between 
the three zones (Figure 3, Table 1). Almost the same pattern is replicated in terms of species abundance. It was found that the upstream zone also contains higher densities of Zygoptera (1026) than within the dam (187) and the zone downstream from the dam (625), while the highest densities of Anisoptera are found in the dammed zones. This high value of Zygoptera abundance upstream is due to a strong proliferation of Coenagrionidae, Calopterygidae, and Platycnemididae. In this zone, about $82 \%$ of the Zygoptera population (1026) concentrates on four species, namely Calopteryx haemorrhoidalis (305), Platycnemis subdilatata (204), Erythromma lindennii (180), and Ischnura graellsii (155) (Table 1). There is an inequitable distribution of individuals among the different taxa, with a value of 0.76 for Pielou's evenness index (Table 2), which could only be explained by the predominance of some species over others. On the other hand, the zones containing the most well-structured and stable odonatological communities were the dammed zones (Z2 and Z3) with equitability values of 0.90 and 0.83 , respectively (Table 2 ). This is probably due to the relatively open and sunny structure of these habitats, which consequently offered ideal conditions for Odonata settlement, especially for generalist species. It can therefore be concluded that the high richness and abundance of damselflies upstream from the dam are due to the well vegetated banks and the presence of shade over this habitat due to the trees and shrubs surrounding the water body; this concurs with the findings of Subramanian (2005), Arulprakash and Gunathilagaraj (2010), Brasil et al. (2014), and Klein et al. (2018) who revealed that shade and aquatic vegetation may favour Zygoptera more than Anisoptera, this is also mentioned by Dijkstra and Lempert (2003), Hofmann and Mason (2005), and Remsburg et al. (2008), when they found that shade strongly affected adult dragonflies. In addition, other environmental changes such as flow modifications and water level fluctuation induced by the dam's construction are also responsible for the change in Odonata assemblages along this watercourse. In fact, the fluctuating water level does not favour regular growth of vegetation along the dam's edges; in addition, changes in water flow convert lotic environments to lentic zones, which favour some Anisoptera species and exclude other Zygoptera species (Carvalho et al. 2013; Denis 2018). This is also mentioned by Samways (1989) when he noted that farm dam construction considerably increases the overall abundance of some ecologically generalist species. The present study produced similar findings to that reported by the authors above. These water flow variations partly explain the loss of Zygoptera richness and the high presence of Anisoptera in the reservoir. The only Zygopterans noted at the dam are ubiquitous species, namely Erythromma lindennii, Coenagrion scitulum, and Ischnura graellsii (Table 1), and other stenotopic damselflies are replaced by generalist dragonflies and those reported from lentic environments, such as Brachythemis impartita and Trithemis annulata. But the loss of Zygopteran species in dammed zones is more important than the increase in Anisopteran species because, in general, rivers are richer in Zygopterans. This upheaval is of concern because it may affect endemic and very narrowly distributed species. Without data on their biology, it is difficult to anticipate which species will be most affected.

Comments on two emblematic species (Onychogomphus uncatus and Calopteryx exul) Onychogomphus uncatus (Charpentier, 1840): O. uncatus is a widespread western Mediterranean species (Boudot et al. 2009). Locally, this species, which prefers flowing water to rocky sandy substrate, is very rare and scarce in the Bejaia area and its numbers are limited to a few individuals (Chelli and Moulai 2019). In this study, only seven individuals were observed downstream of the Boussellam watercourse; however, reproductive behaviour was noted in mid-June and a few exuviae were found under the rocks. This species is extremely scarce in Numidia, and most records from other regions of northern Algeria are old and scattered. It is much less common than $O$. forcipatus unguiculatus and $O$. costae due to the ecological requirements of the larvae, which need clear and well-oxygenated water (D'Aguilar and Dommanget 1998). Its status is listed as Least Concern (LC) on all IUCN Red Lists. However, the current situation of $O$. uncatus is concerning and remains a subject of debate on a regional scale. Its status in North Africa is listed as Least Concern (LC) on the IUCN North African Red List (Samraoui et al. 2010), but this evaluation rests on the abundance of the species in Morocco and the range believed to span Morocco, Algeria and Tunisia. Past records of $O$. uncatus from Algeria are old (Lacroix 1925; Martin 1910; Morton 1905), misidentified (Khelifa et al. 2011) or based on larvae (Benchalel and Samraoui 2012; Samraoui and Corbet 2000a), and only a few individuals collected (Hamzaoui et al. 2015; Chelli and Moulai 2019a; this study).

In Algeria, the rarity and population decrease of this species is the result of the anthropisation of its habitats due to gravel extraction, dyking and pollution. For this reason, $O$. uncatus requires a special conservation status and its habitats must be preserved. The other three species, O. forcipatus, G. lucassi, and G. costae, should not be neglected either, although their conservation status is not of concern.

Calopteryx exul Selys, 1853: This endemic and emblematic Maghrebian species is restricted to a narrow range extending from northern Tunisia to Morocco. It is confined to streams and rivers (Boudot et al. 2009) and 
is currently listed as endangered (EN) in the Mediterranean and North African IUCN Red Lists. In Algeria, this damselfly was not recorded from 1910 (Martin 1910) until 2007, when a new population was discovered on the Seybouse River in northeast Algeria (Khelifa et al. 2011). Later, different sub-populations were recorded in the Seybouse watershed (Khelifa et al. 2016; Khelifa and Mellal 2017; Mellal et al. 2018; Bouhala et al. 2019). Last year, in April 2019, a new population of this species was discovered in the Boussellam watercourse in Bejaia province, central north Algeria (Chelli et al. 2019). The environmental characteristics as well as the damselfly communities living with this species in this watercourse are relatively similar to those recorded in the Seybouse River (Khelifa et al. 2011, 2014). In the Seybouse watershed, the species has a patchy distribution and lives in subpopulations that might be connected by dispersal (Khelifa 2016). Effectively, the population noted upstream from the dam is reduced to a subpopulation downstream due to the dam construction. This is in accordance with the observations of Khelifa and Mellal (2017) who reported that many subpopulations have become extinct, mainly due to habitat disturbance, including bank degradation and irrigation.

The population of C. exul reported here occurs on Typha angustifolia and Scirpus lacustris where breeding and egg-laying behaviour were observed, whereas Mellal et al. (2018) have shown that Potamogeton nodosus was used very significantly for oviposition in $C$. exul compared to T. angustifolia .

This watercourse can be considered the second most important site where this species occurs in Algeria after the Seybouse watershed. This new finding extends the known geographic range of the extant populations of the species in Algeria. Consequently, effective conservation strategies to protect the global structure of this watercourse are required.

Both species can be considered to be key species because they are very sensitive to environmental changes in our rivers, especially gomphids, which are considered reliable indicators of a healthy river system (FerrerasRomero et al. 2009).

\section{CONCLUSION}

Although of a preliminary nature and constrained by its small sample size, this study made it possible to draw up a list of Boussellam watercourse dragonflies and to update the Odonata list for the Bejaia region and also allowed us to identify the potential impacts that artificialization can generate on a watercourse using Odonata as a biological model. In future studies, adult Odonata should be investigated in combination with larvae and exuviae sampling because some species are strong fliers and adults may easily escape detection.

Despite the strong signs of disturbance noted in this watercourse, it is still one of the most interesting wadis in the whole Bejaia region. With a richness of 23 species, which represents $60 \%$ of the local odonatological fauna, it suggests that the quality of its water is still good enough to support some stenotopic species, such as the critically endangered Calopteryx exul and the scarce species Onychogomphus uncatus, although the surrounding landscape is damaged by this dam. This richness also shows the importance of this wadi on a regional and national scale, and the fact that it is home to one of the known Algerian populations of C. exul, a species in strong drift throughout its range, makes it essential to apply effective conservation strategies aimed at protecting the global structure and chemical quality of this watercourse. In addition, it is now recognized that if development is to be sustainable, the effects of dams on ecosystems and the wildlife they support cannot be overlooked. Minimizing the negative environmental impacts of dams must become a priority for dam builders and environmental managers.

Results shown in this study strongly indicate the negative impact of the Tichi Haf dam on the dragonfly fauna because of the changes caused by this barrier on the Boussellam watercourse, especially on its riperian vegetation and bank structure as well as the water conditions, which have considerably reduced the richness and diversity of Odonata species. Indeed, the composition of the Odonata assemblages found upstream from the dam is considerably different from those found downstream from this barrier.

Finally, our approach allows us to make an initial assessment of the impacts but does not provide cogent explanations about the genesis of these impacts. Further investigations are needed, involving a greater number of dams, to confirm this pattern and to obtain a clear idea of the real impacts that these constructions can generate on watercourses. We also recommend that the observed pattern be verified through analysis of other taxonomic groups on a more expansive spatial scale.

We recognize that the patterns identified in the present study are preliminary, and we hope to continue the research in the coming years on a wider spatial scale and would like other researchers to replicate this study in other localities to gather more information on the impacts of dams on Odonata communities.

\section{ACKNOWLEDGEMENTS}

We are grateful to the reviewers for their helpful comments which improved the first version of the manuscript 
and to colleagues D. Amalou and R. Zebsa for accompanying us in the field. We would also like to thank F. Bekdouche for the plant determination, without forgetting H. Baaziz, LZAEA lab manager who provided us with the field equipment.

\section{ORCID ID: HTTPS://ORCID.ORG/0000- 0001-9133-2761}

\section{REFERENCES}

Arulprakash, R., and K. Gunathilagaraj. 2010. Abundance and diversity of Odonata in temporary water bodies of Coimbatore and Salem districts in Tamil Nadu. Journal of Threatened Taxa 2 (8): 1099-1102.

Belmar, O., J. Velasco, F. Martínez-Capel, and A. A. Marín. 2010. Natural flow regime, degree of alteration and environmental flows in the Mula stream (Segura River basin, SE Spain). Limnetica 29 (2): 353-368.

Benchalel, W., and B. Samraoui. 2012. Caractérisation écologique et biologique de l'odonatofaune de deux cours d'eau méditerranéens: 1'oued El-Kébir et l'oued Bouaroug (Nord-Est de l'Algérie). [Ecological and biological characterization of the odonato-fauna of two Mediterranean rivers: the wadi El-Kébir and the wadi Bouaroug (North-East Algeria)]. Méditerranée 118: 19-27.

Boudot, J. P., V. J. Kalkman, M. Azpilicueta Amorín, T. Bogdanović, A. Cordero Rivera, G. Degabriele, J. L. Dommanget, S. Ferreira, B. Garrigós, M. Jović, M. Kotarac, W. Lopau, M. Marinov, N. Mihoković, E. Riservato, B. Samraoui, and W. Schneider. 2009. Atlas of the Odonata of the Mediterranean and North Africa. Libellula Supplement 9: 1-256.

Bouhala, Z., C. Khemissa, J. Márquez-Rodríguez, M. Ferreras-Romero, F. Samraoui, and B. Samraoui. 2019. Ecological correlates of odonate assemblages of a Mediterranean stream, Wadi Cherf, northeastern Algeria: implications for conservation. International Journal of Odonatology 22 (3/4): 181-197.

Brasil, L. S., N. F. d. s. Giehl, S. M. Almeida, M. B. X. Valadão, J. O. Dos Santos, N. S. Pinto, and J. D. Batista. 2014. Does the damming of streams in the southern Amazon basin affect dragonfly and damselfly assemblages (Odonata: Insecta)? A preliminary study. International Journal of Odonatology 17 (4): 187-197.

Bredenhand, E., and M. J. Samways. 2009. Impact of a dam on benthic macroinvertebrates in a small river in a biodiversity hotspot: Cape Floritic Region, South Africa. Journal of Insect Conservation 13 (3): 297-307.

Carvalho, F. G., N. S. Pinto, J. M. B. Oliveira-Junior, and L. Juen. 2013. Effects of marginal vegetation removal on Odonata communities. Acta Limnologica Brasiliensia 25 (1): 10-18.

Chelli, A., and R. Moulaï. 2019a. Ecological characterization of the odonatofauna in lotic and lentic waters of northeast Algeria. Annales de la Société entomologique de France (N. S.) 55 (5): 430-445.

Chelli, A., and R. Moulaï. 2019b. Diversity and ecological diagnosis of dragonflies of high-mountain temporary ponds in the Akfadou massif forest (Algeria). Zoology and Ecology 29 (1): 28-37.

Chelli, A., R. Zebsa, and R. Khelifa. 2019. Discovery of a new population of the endangered Calopteryx exul in central North Algeria (Odonata: Calopterygidae). Notulae odonatologicae 9 (4): 150-154.

Clausnitzer, V., V. J. Kalkman, M. Ram, B. Collen, J. E. M. Baillie, M. Bedjani, W. R. T. Darwall, K. D. B. Dijkstra, R. Dow, J. Hawking, et al. 2009. Odonata enter the biodiversity crisis debate: the first global assessment of an insect group. Biological Conservation 142 (8): 1864-1869.

Clausnitzer, V., K. D. B. Dijkstra, R. Koch, J. P. Boudot, W. R. Darwall, J. Kipping, et al. 2012. Focus on African freshwaters: Hotspots of dragonfly diversity and conservation concern. Frontiers in Ecology and the Environment 10 (3): 129-134.

C. M. B. 2000. Barrages et développement. Un nouveau cadre pour la prise de décisions. Tour d'horizon. Le Rapport de la Commission Mondiale des barrages. Novembre 2000. [Dams and development. A new framework for decision-making. An overview. The Report of the World Commission on Dams]. Available from: www.dams.org

Corbet, P. S. 1999. Dragonflies: Behaviour and Ecology of Odonata. New York: Cornell University Press.

D'Aguilar, J., and J. L. Dommanget. 1998. Guide des libellules d'Europe et d'Afrique du Nord. 2ème Ed. [European and North African Dragonflies Guide. 2nd Ed.] Paris: Delachaux and Niestlé.

Denis, A. S. 2018. Impacts de l'anthropisation sur la diversité odonatologique au sein des cours d'eau : vers une meilleure prise en compte des espèces de la Directive Habitats Faune Flore. [Impacts of anthropisation on odonatological diversity within watercourses: towards a better consideration of the species of the Habitats and Fauna Flora Directive]. Thèse de l'Université Toulouse 3 Paul Sabatier.

Dessaix, J., J. F. Fruget, J. M. Olivier, and J. L. Beffy. 1995. Changes of the macroinvertebrate communities in the dammed and by-passed sections of the French upper Rhône after regulation. Regulated Rivers: Research and Management 10: 265-279.

Dijkstra, K. D. B. 2007. Demise and rise: the biogeography and taxonomy of Odonata of tropical Africa. $\mathrm{PhD}$ Thesis, Department of Biology, Faculty of Mathematics and Natural Sciences, Leiden University. 
Dijkstra, K. D. B., and J. Lempert. 2003. Odonate assemblages of running waters in the Upper Guinean forest. Archiv für Hydrobiologie 157: 397-412.

Dudgeon, D., A. H. Arthington, M. O. Gessner, Z. I. Kawabata, D. J. Knowler, C. Lévêque, R. J. Naiman, A. H. Prieur-Richard, D. Soto, M. J. L. Stiassny, and C. A. Sullivan. 2006. Freshwater biodiversity: importance, threats, status and conservation challenges. Biological Reviews 81 (2): 163-182.

Ferreras-Romero, M., J. Marquez-Rodriguez, and A. RuizGarcia. 2009. Implications of anthropogenic disturbance factors on the Odonata assemblage in a Mediterranean fluvial system. International Journal of Odonatology 12: 413-428.

Fulan, J. A. A., R. Raimundo, D. Figueuredo, and M. Correia. 2010. Abundance and diversity of dragonflies four years after the construction of a reservoir. Limnetica 29 (2): 279-286.

García, N., A. Cuttelod, and D. Abdul Malak (eds). 2010. The status and distribution of freshwater biodiversity in Northern Africa. Gland (Switzerland, Cambridge, UK, and Malaga, Spain): IUCN; xiii + 141 pp. Available from: http:/cmsdata.iucn.org/downloads/ the_status_and_distribution_of_freshwater_biodiversity_in_northern_africa.pdf

Grand, D. 2009. Les Libellules et le réchauffement climatique. [Dragonflies and climate change]. Revue des sciences Bourgogne-Nature (9/10): 124-133.

Grand, D., and J. P. Boudot. 2006. Les Libellules de France, Belgique et Luxembourg. [The Dragonflies of France, Belgium and Luxembourg]. Éditions Biotope, Collection Parthénope, Mèze.

Hamzaoui, D., M. Hafiane, M. Mebarkia, A. Araba, A. H. Alfarhan, and B. Samraoui. 2015. The Gomphidae of Algeria and the Maghreb: status, ecology and conservation (Insecta: Odonata). International Journal of Odonatology 18 (3): 175-191.

Heidemann, H., and R. Seidenbusch. 2002. Larves et exuvies des libellules de France et d'Allemagne (sauf de Corse). [Larvae and exuviae of dragonflies from France and Germany (except Corsica)]. Bois-d'Arcy: Société française d'Odonatologie.

Hofmann, T. A., and C. F. Mason. 2005. Habitat characteristics and the distribution of Odonata in a lowland river catchment in eastern England. Hydrobiologia 539: 137-147.

Indermuehle, N., S. Angélibert, and B. Oertli. 2008. IBEM: Indice de Biodiversité des Etangs et Mares. Manuel d'utilisation. [IBEM: Index of Biodiversity of Ponds. User's manual]. Ecole d'Ingénieurs HES de Lullier, Genève.

Kalkman, V. J., V. Clausnitzer, K. D. B. Dijkstra, A. G. Orr, D. R. Paulson, and J. Van Tol. 2008. Global diversity of dragonflies (Odonata) in freshwater. Hydrobiologia 595: 351-363.
Khelifa, R. 2016. Partial bivoltinism and emergence patterns in the North African endemic damselfly Calopteryx exul: conservation implications. African Journal of Ecology 55: 145-151.

Khelifa, R. 2019. Sensitivity of biodiversity indices to life history stage, habitat type and landscape in Odonata community. Biological Conservation 237: 63-69.

Khelifa, R., and M. K. Mellal. 2017. Host-plant-based restoration as a potential tool to improve conservation status of odonate specialists. Insect Conservation and Diversity 10 (2): 151-160.

Khelifa, R., A. Youcefi, A. Kahalerras, A. H. Alfarhan, K. A. S. Al-Rasheid, and B. Samraoui. 2011. L'odonatofaune de la Seybouse en Algérie: intérêt pour la biodiversité du Maghreb (Insecta: Odonata). [The odonato-fauna of the Seybouse in Algeria: interest for the biodiversity of the Maghreb (Insecta: Odonata)]. Revue d'Ecologie (Terre et Vie) 66: 55-66.

Khelifa, R., R. Zebsa, N. E. Sakrane, A. Youcefi, S. Bensouilah, and H. Amari. 2014. Long-range movements of an endangered endemic damselfly Calopteryx exul Selys, 1853 (Calopterygidae: Odonata). African Journal of Ecology 52: 375-377.

Khelifa, R., R. Zebsa, H. Amari, M. K. Mellal, H. Mahdjoub, and A. Kahalerras. 2016. A hotspot for threatened Mediterranean odonates in the Seybouse River (Northeast Algeria): are IUCN population sizes drastically underestimated? International Journal of Odonatology 19: 1-11.

Klein, C. E., N. S. Pinto, Z. A. V. Spigoloni, F. M. Bergamini, F. R. De Melo, P. J. De Marco, and L. Juen. 2018. The influence of small hydroelectric power plants on the richness and composition of Odonata species in the Brazilian Savanna, International Journal of Odonatology 21 (1): 33-44.

Lacroix, J. L. 1925. Quelques Névroptères (sens. Lat.) d'Afrique. [Some Neuropterans from Africa]. Bulletin de la Société d'Histoire naturelle d'Afrique du Nord 16: 258-263.

Lessard, J. L., and D. B. Hayes. 2003. Effects of elevated water temperature on fish and macroinvertebrate communities below small dams. River Research Applications 19: 721-732.

Lévêque, C. 2005. Environmental impacts of dams. Les Colloque de l'Académie d'Agriculture de France «Irrigation et Développement Durable» (1): 33-43. Paris, 19 mai. 2005.

Martin, R. 1910. Contribution à l'étude des Neuroptères de l'Afrique. II. Les odonates du département de Constantine. [Contribution to the study of African Neuroptera. II. Odonates from the department of Constantine]. Annales de la Société Entomologique de France 79: 95-104.

May, M. L. 1976. Thermoregulation in adaptation to temperature in dragonflies (Odonata: Anisoptera). Ecological Monographs 46: 1-32. Retrieved from: http://www. jstor.org/stable/1942392 
Mc Cartney, M. 2009. Living with dams: managing the environmental impacts. Water Policy 11 (1): 121-139.

Mellal, M. K., M. Bensouilah, M. Houhamdi, and R. Khelifa, R. 2018. Reproductive habitat provisioning promotes survival and reproduction of the endangered endemic damselfly Calopteryx exul. Journal of Insect Conservation 22 (3/4): 563-570.

Morton, K. J. 1905. Odonata collected by Miss M. Fountaine in Algeria, with description of a new species of Ischnura. Entomology Monthly Magazine S. 2 (16): 146-149.

Oller, C., and E. Goitia. 2005. Benthic macroinvertebrate and heavy metals in the Pilcomayo River (Tarija, Bolivia). Revista Boliviana de Ecología 18: 17-32.

Raebel, E. M., T. Merckx, P. Riordan, D. W. Macdonald, and D. J. Thompson. 2010. The dragonfly delusion: why it is essential to sample exuviae to avoid biased surveys. Journal of insect Conservation 14: 523-533.

Remsburg, A. J, A. C. Olson, and M. J. Samways. 2008. Shade Alone Reduces Adult Dragonfly (Odonata: Libellulidae) Abundance. Journal of Insect Behavior 21 (6): 460-468.

Richter, B. D., D. P. Braun, M. A. Mendelson, and L. L. Master. 1997. Threats to imperilled freshwater fauna. Conservation Biology 11 (5): 1081-1093.

Riservato, E., J. P. Boudot, S. Ferreira, M. Jovic, V. J. Kalkman, W. Schneider, B. Samraoui, and A. Cuttelod. 2009. The Status and Distribution of Dragonflies of the Mediterranean Basin. Gland, Switzerland and Malaga, Spain. IUCN: vii + 33 p.

Samraoui, B., and R. Menaï. 1999. A contribution to the study of Algerian Odonata. International Journal of Odonatology 2 (2): 145-165.

Samraoui, B., and P. S. Corbet. 2000a. The odonata of Numidia, northeastern Algeria. Part I. Status and distribution. International Journal of Odonatology 3 (1): 11-25.

Samraoui, B., and P. S. Corbet. 2000b. The odonata of Nu- midia, northeastern Algeria. Part II. Seasonal ecology. International Journal of Odonatology 3 (1): 27-39.

Samraoui, B., J. P. Boudot, S. Ferreira, E. Riservato, M. Jović, V. J. Kalkman, and W. Schneider. 2010. The status and distribution of dragonflies (Odonata). Chapter 5. In The status and distribution of freshwater biodiversity in Northern Africa. Gland (Switzerland and Malaga, Spain), edited by Garcia, N., A. Cuttelod, and D. Abdul Malak, 51-70. IUCN. Available from: http:// cmsdata.iucn.org/downloads/the_status_and_distribution_of_freshwater_biodiversity_in_northern_africa. pdf

Samways, M. J. 1989. Farm dams as nature reserves for dragonflies (Odonata) at various altitudes in the Natal Drakensburg mountains, South Africa. Biological Conservation 48: 181-187.

Smith, K. G., and W. R. T. Darwall (comp.) 2006. The Status and Distribution of Freshwater Fish Endemic to the Mediterranean Basin. IUCN, Gland, Siwtzerland and Cambridge, UK. v +34 pp.

Subramanian, K. A. 2005. Dragonflies and Damselflies of Peninsular India: A Field Guide. Bangalore, India: Project Lifescape, Indian Academy of Science.

Thomson, J. R., D. D. Hart, D. F. Charles, T. L. Nightengale, and D. M. Winter. 2005. Effects of removal of a small dam on downstream macroinvertebrate and algal assemblages in a Pennsylvania stream. Journal of the North American Benthological Society 24 (1): 192-207.

Thorne, R. J., and W. P.Williams. 1997. The response of benthic macroinvertebrates to pollution in developing countries: a multimetric system of bioassessment. Freshwater Biology 37: 671-686.

Tonkin, J. D., R. G. Death, and M. K. Joy. 2009. Invertebrate drift patterns in a regulated river: dams, periphyton biomass or longitudinal patterns? River Research and Applications 25 (10): 1205-1338. 